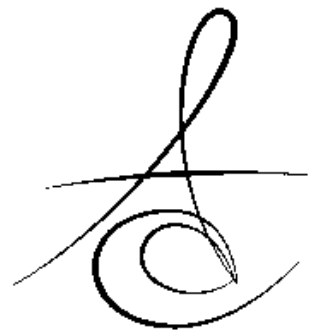

\title{
AN IN VITRO STUDY OF THE EFFECTS OF DIFFERENT TORQUE VALUES APPLIED TO THE NICKEL TITANIUM ROTARY CANAL INSTRUMENTS FOR CURVED ROOT CANAL PREPARATION ${ }^{*}$
}

\section{NİKEL TİTANYUM DÖNER KANAL ALETLERİNE UYGULANAN FARKLI TORK DEĞERLERİNİN EĞRİ KÖK KANAL PREPARASYONUNA ETKİLERİNİN İN VİTRO OLARAK İNCELENMESI ${ }^{*}$}

Yrd. Doç. Dr. Demet ALTUNBAŞ*

Doç. Dr. Kerem Engin AKPINAR*

Doç. Dr. Alper KUŞTARCI**

Makale Kodu/Article code: 1963

Makale Gönderilme tarihi; 10.11 .2014

Kabul Tarihi: 29.12.2014

\section{ABSTRACT}

Aim: To evaluate the effects of different torque values applied to K3 and Mtwo instruments on curved canal preparation in vitro.

Material and Methods: One-hundred-twenty resin blocks with curved canals were divided into two main groups in which $\mathrm{K} 3$ and Mtwo series were used. The main groups were then divided into three subgroups. Torque values were set at $20 \mathrm{gcm}, 60 \mathrm{gcm}$ and 120 $\mathrm{gcm}$ in the $\mathrm{K} 3$ group and $100 \mathrm{gcm}, 150 \mathrm{gcm}$ and 300 $\mathrm{gcm}$ in the Mtwo group. Pre- and post-instrumentation images were superimposed and canal shape was assessed. Measurements were carried out at 5 different points: at the canal orifice $(0)$; half-way to the orifice in the straight section $(\mathrm{HO})$; beginning of the curve (BC); apex of the curve (AC); endpoint (EP). Results: In the $\mathrm{K} 3$ and Mtwo groups, the narrowest total width measurements were recorded at the subgroups that the torque was highest. In the K3 group, there were significant differences for the amount of resin removed from the outer curve at $\mathrm{O}$, $\mathrm{BC}$ and $\mathrm{AC}$; for the amount of resin removed from the inner curve at $\mathrm{HO}, \mathrm{BC}, \mathrm{AC}$ and $\mathrm{EP}$. In the Mtwo group, significant differences were found for the amount of resin removed from the outer curve at $\mathrm{HO}, \mathrm{BC}, \mathrm{AC}$ and $E P$; and for the amount of resin removed from the inner curve at $\mathrm{AC}$.

Conclusion: K3 instruments shaped curved canals with minimal transportation, when the torque value increased; on the contrary, greater values of absolute transportation occured with Mtwo instruments.

Keywords: root canal preparation, torque, transportation

\section{ÖZET}

Amaç: Bu çalışmanın amacı K3 ve Mtwo eğelerine uygulanan farklı tork değerlerinin, eğri kök kanal preparasyonuna etkilerinin in vitro olarak değerlendirilmesidir.

Gereç ve Yöntem: 120 adet eğri kanallı rezin blok K3 ve Mtwo serilerinin kullanıldığı iki ana gruba ayrıldı. Ana gruplar daha sonra 20'er bloktan oluşan üç alt gruba ayrıldı. Tork değerleri K3 grubunda $20 \mathrm{gcm}, 60$ $\mathrm{gcm}$ ve $120 \mathrm{gcm}$; Mtwo grubunda $100 \mathrm{gcm}, 150 \mathrm{gcm}$ ve $300 \mathrm{gcm}$ olarak belirlendi. Enstrümentasyon öncesi ve sonrası görüntüler çakıştırıldı ve kanal şekli değerlendirildi. Ölçümler 5 farklı noktada yapıldı: kanal ağzı (O), kanal ağzı ile eğimin başlangıcı arasındaki uzaklığın orta noktası (HO), eğimin başlangıcı (BC), eğimin apeksi (AC), son nokta (EP).

Bulgular: K3 ve Mtwo gruplarında en dar toplam kanal genişliği ölçümleri, torkun en yüksek olduğu alt gruplarda kaydedildi. K3 grubunda, eğimin dış tarafından kaldırılan madde miktarı yönünden $\mathrm{O}, \mathrm{BC}$ ve $A C$ ölçüm noktalarında ve eğimin iç tarafından kaldırılan madde miktarı yönünden $\mathrm{HO}, \mathrm{BC}, \mathrm{AC}$ ve EP ölçüm noktalarında istatistiksel farklılık anlamlı bulundu. Mtwo grubunda, eğimin dış tarafından kaldırılan madde miktarı yönünden $\mathrm{HO}, \mathrm{BC}, \mathrm{AC}$ ve EP ölçüm noktalarında ve eğimin iç tarafından kaldırılan madde miktarı yönünden AC ölçüm noktasında istatistiksel farklılık anlamlı bulundu.

Sonuç: K3 eğeleri tork değeri arttığında eğimli kanalları minimum trasportasyonla şekillendirdi; tam tersine, tork değeri arttığında Mtwo eğelerle daha büyük değerlerde transportasyon meydana geldi.

Anahtar Kelimeler: kök kanal preparasyonu, tork, transportasyon

*Department of Endodontics, Faculty of Dentistry, Cumhuriyet University

**Department of Endodontics, Faculty of Dentistry, Akdeniz University

\# This study was supported by Cumhuriyet University Scientific Research Projects

(Diş-075, CUBAP, Sivas, Turkey).

\# This study was presented as an oral presentation in $11^{\text {th }}$ International Congress of the

Turkish Endodontic Society, Istanbul, April 27-28, 2012.

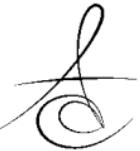




\section{INTRODUCTION}

Although successful treatment depends on many factors, one of the most important steps in any root canal treatment is canal preparation because it determines the efficacy of all subsequent procedures. ${ }^{1}$ One of the main objectives of canal preparation is to shape and clean the root canal system effectively whilst maintaining the original configuration without creating any iatrogenic events such as instrument fracture, external transportation, ledge or perforation. ${ }^{2}$

To minimize iatrogenic procedural errors, nickel titanium ( $\mathrm{Ni}-\mathrm{Ti})$ rotary instruments recently have been introduced. ${ }^{3} \mathrm{Ni}$-Ti rotary instruments which may have particular promise for the clinical preparation of curved root canals, have a two to three times higher elastic flexibility and a superior resistance to torsional fracture compared with the conventional stainless steel files. ${ }^{4}$ In comparison with stainless steel files, $\mathrm{Ni}-\mathrm{Ti}$ rotary instruments prepared curved canals rapidly and with less canal transportation towards the outer aspect of the curve. ${ }^{5,6}$ Furthermore, $\mathrm{Ni}-\mathrm{Ti}$ rotary instruments created few aberrations such as zips, danger zones and perforations. ${ }^{7-9}$ These instruments have been developed in various designs in order to improve working safety, shorten preparation time and create a continuously tapered, conical flare of preparation. ${ }^{10}$

New $\mathrm{Ni}-\mathrm{Ti}$ rotary instruments with different configuration and design have been introduced as Mtwo (VDW, Munich, Germany) and K3 (SybronEndo, West Collins, CA, America).

Mtwo instruments have an S-shaped crosssectional design with a noncutting safety tip. These instruments are characterised by a positive rake angle with two cutting edges. Mtwo instruments have an increasing pitch from the tip to the handle to eliminate threading and binding in continuous rotation, and to reduce the transportation of debris towards the apex. ${ }^{11}$ The basic series of Mtwo instruments includes in the sizes 10/.04 taper, 15/.05 taper, 20/.06 taper, 25/.06 taper, 25/.07 taper, 30/.05 taper, 35/.04 taper and 40/.04 taper. According to the manufacturer these instruments are used at $300 \mathrm{rpm}$ and used in a single length technique without any early coronal enlargement. ${ }^{12}$

The K3 instruments have a slightly positive rake angle in combination with so-called radial land relief and asymmetrical cross-sectional design. ${ }^{13}$ The peripheral blade relief areas are alleged to have two functions: (i) to increase the peripheral mass in order to increase the instruments resistance to fracture and (ii) to reduce the amount of area of the radial lands that comes in contact with the canal wall in order to reduce frictional resistance. ${ }^{6} \mathrm{~K} 3$ files are available in 6 different tapers from .02 to .12 with a multitude of lengths and tip sizes.

There have been several investigations on the effects of different factors on the shaping ability of $\mathrm{Ni}$ Ti rotary instruments in curved canals such as angle and radius of the curvature, rotational speed, instrument type and preparation technique. ${ }^{14-17}$

Torque is another changeable parameter in the root canal preparation. Torque, also called moment or moment of force, is the tendency of a force to rotate an object about an axis, fulcrum, or pivot. When the instrument used with a high torque motor, it is very active and the incidence of instrument locking and consequently, deformation and separation would tend to increase. Whereas a low torque would reduce the cutting efficiency of the instrument and instrument progression in the canal would be difficult; the operator would then tend to force the instrument and may encourage instrument locking, deformation, and separation. $^{18}$

Recently, there have been many studies about the effects of different torque values on the incidence of instruments locking, deformation and separation. ${ }^{18-}$ ${ }^{22}$ However, there was no study about the effects of torque values on canal transportation and straightening, perforation, ledge, zip-elbow formation and change of working length. Thus, the purpose of this study was to evaluate the effects of different torque values applied to K3 and Mtwo instruments on simulated curved canal preparation.

\section{MATERIALS AND METHODS}

One-hundred-twenty transparent resin blocks (FlexMaster Übungsblocks, Ref. V040245, Germany) with a mean degree of curvature of $35 \pm 4$ were used to assess instrumentation. The canals were $19 \mathrm{~mm}$ long in total with a straight part of $13 \mathrm{~mm}$ and a curved part of $6 \mathrm{~mm}$.

The blocks with simulated canals were randomly divided into two main groups and prepared with K3 (SybronEndo, West Collins, CA, America) and Mtwo (VDW, Münih, Germany) Ni-Ti rotary systems.

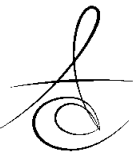


The main groups were then divided into three subgroups of 20 each. Shaping was completed using VDW.GOLD (VDW, Munich, Germany) electric torque control motor. In the $\mathrm{K} 3$ group, the rotational speed was set at $300 \mathrm{rpm}$. The torque was set at 20,60, 120 $\mathrm{gcm}$ for subgroups 1,2 and 3 , respectively. In the Mtwo group, the rotational speed was set at $280 \mathrm{rpm}$. The torque was set at 100, 150, $300 \mathrm{gcm}$ for subgroups 4,5 and 6 , respectively. All canals were prepared to a working length of $18.5 \mathrm{~mm}$ and all instruments were used to shape four canals only. Each resin block was covered with aluminium leaf during the instrumentation. Copious irrigation with distilled water was used during the preparation. Also, all canals were prepared by one operator to reduce interoperator variability.

\section{Preparation of simulated canals}

Each canal was prepared using a gentle in-andout motion. Once a file had negotiated to the end of the canal and had rotated freely it was removed and inspected.

Group M. Mtwo instruments were used to full working length of the canals according to the manufacturer's instructions. The instrumentation sequence was:

1. A 0.04 taper size 10 instrument was used to $\mathbf{1 8 . 5}$ $\mathrm{mm}$.

2. A 0.05 taper size 15 instrument was used to 18.5 $\mathrm{mm}$.

3. A 0.06 taper size 20 instrument was used to 18.5 $\mathrm{mm}$.

4. A 0.06 taper size 25 instrument was used to 18.5 $\mathrm{mm}$.

5. A 0.05 taper size 30 instrument was used to 18.5 $\mathrm{mm}$.

6. A 0.04 taper size 35 instrument was used to 18.5 $\mathrm{mm}$.

Group K. K3 instruments were used in a crowndown manner according to the manufacturer's instructions. The sequence was:

1. A 0.06 taper size 20 instrument was used to $9 \mathrm{~mm}$.

2. A 0.04 taper size 30 instrument was used to 12 $\mathrm{mm}$.

3. A 0.04 taper size 25 instrument was used to 14 $\mathrm{mm}$.

4. A 0.04 taper size 20 instrument was used to 16 $\mathrm{mm}$.
5. A 0.02 taper size 20 instrument was used to 18.5 $\mathrm{mm}$.

6. A 0.02 taper size 25 instrument was used to $\mathbf{1 8 . 5}$ $\mathrm{mm}$.

7. A 0.02 taper size 30 instrument was used to $\mathbf{1 8 . 5}$ $\mathrm{mm}$.

8. A 0.02 taper size 35 instrument was used to $\mathbf{1 8 . 5}$ $\mathrm{mm}$.

\section{Assessment of preparation}

Pre- and post-instrumentation canal shapes were photographed in a standardized manner using a digital camera. A composite image was produced of the pre- and post-instrumentation images and superimposed using Adobe Photoshop CS3 (Adobe System, San Jose, CA, USA). Measurements were made on superimposed images using the Image J $1.42 \mathrm{q}$ computer program (National Institutes of Health, USA) with an accuracy level of $0.001 \mathrm{~mm}$.

The removed resin was measured at five reference points (Figure 1) established on each canal, using a method described by Calberson et al. ${ }^{23}$ :

- Point 1: the canal orifice $(\mathrm{O})$,

- Point 2: half-way from the beginning of the curve to the orifice $(\mathrm{HO})$,

- Point 3: the beginning of the curve (BC),

- Point 4: the apex of the curve of the original canal $(A C)$,

- Point 5: endpoint of the preparation (EP).

Using pre- and post-instrumentation images, the angle of curvatures were determined according to the method described by Bone ve Moule ${ }^{24}$ with Image J 1.42q (National Institutes of Health, USA).

Different types of canal aberrations such as zip, elbow, ledge and perforation were assessed on the images of superimposed canals. These aberrations were defined according to the descriptions of Thompson and Dummer?

Instruments were examined after every use and instrument deformation and separation within each subgroup were recorded. In case of instrument deformation and separation before completing the cleaning and shaping, the instrument was replaced.

The final length of each canal was determined following preparation. Change of working length was determined by subtracting the final length from the original length $(18.5 \mathrm{~mm})$. 


\section{Statistical analysis}

Statistical analysis of the collected data was performed using SPSS 14.0 (SPSS, Inc., Chicago, IL, USA). Kruskal-Wallis, Tukey, and Chi-square tests were used. p-values less than 0.05 were considered statistically significant.

\section{RESULTS}

\section{Total width measurements}

Table 1 shows the mean total widths of the canals at the various measurement positions. There were statistically significant differences $(p<0.05)$ in the total width of the canals in the $\mathrm{K} 3$ group at $\mathrm{O}$ and AC. The canals were the narrowest in the subgroup 3 at these measurement points.

There were statistically significant differences in the total width of the canals in the Mtwo group at AC and EP. The canals were the narrowest in the subgroup 6 at AC and EP.

\section{Inner width measurements}

Table 2 shows the mean widths of resin removed from the inner aspect of the canals. There were significant differences $(p<0.05)$ for the amount of resin removed from the inner aspect of the curve in the $\mathrm{K} 3$ group at $\mathrm{HO}, \mathrm{BC}, \mathrm{AC}$ and $\mathrm{EP}$. Little resin was removed from the inner aspect of the curve at $\mathrm{HO}$ and EP in the subgroup 1. K3 instruments removed less resin in the subgroup 3 at $\mathrm{BC}$; and in the subgroup 2 at $\mathrm{AC}$.

There was statistically significant difference ( $p$ $<0.05$ ) for the amount of resin removed from the inner aspect of the curve in the Mtwo group at AC. More preparation occured in the subgroup 6 at AC.

\section{Outer width measurements}

Table 2 shows the mean widths of resin removed from the outer aspect of the canals. There were statistically significant differences $(p<0.05)$ for the amount of resin removed from the outer aspect of the curve in the $\mathrm{K} 3$ group at $\mathrm{O}, \mathrm{BC}$ and $\mathrm{AC}$. The resin removal from the outer aspect of the curve was greatest in the subgroup 1 at $O$ and in the subgroup 3 at $\mathrm{BC}$. Little resin was removed from the outside of the curve in the subgroup 3 at AC.

There were statistically significant differences $(p<0.05)$ for the amount of resin removed from the outer aspect of the curve in the Mtwo group at $\mathrm{HO}$, $B C, A C$ and EP. The resin removal from the outer aspect of the curve was least in the subgroup 6 at these measurement points.

\section{Absolute amount of transportation}

The degree of absolute transportation irrespective of direction is detailed in Table 3. There were significant differences $(p<0.05)$ for the amount of absolute transportation in the $\mathrm{K} 3$ group at $\mathrm{HO}, \mathrm{BC}$, $\mathrm{AC}$ and EP. The magnitude of absolute transportation was least in the subgroup 3 at $\mathrm{HO}, \mathrm{BC}$ and EP. Most transportation occurred in the subgroup 2 at $A C$.

There were significant differences $(p<0.05)$ for the amount of absolute transportation in the Mtwo group at the beginning of the curve and the apex of the curve. The magnitude of absolute transportation was greatest in the subgroup 6 at these measurement points.

Table 1 . Mean total widths $(\mathrm{mm})$ of canals by torque values

\begin{tabular}{|c|c|c|c|c|c|c|c|}
\hline & & & Orifice & Half-way to orifice & Beginning of curve & Apex of curve & $0.5 \mathrm{~mm}$ from endpoint \\
\hline \multirow{2}{*}{$\begin{array}{l}\text { 음 } \\
\text { 음 } \\
\text { טั้ }\end{array}$} & $\underline{\underline{y}}$ & $\begin{array}{l}\text { Subgroup } 1 \\
\text { Subgroup } 2 \\
\text { Subgroup } 3 \\
\text { p-values }\end{array}$ & $\begin{array}{l}0.638^{a, b} \\
0.626^{a, c} \\
0.613^{b, c} \\
0.001^{*}\end{array}$ & $\begin{array}{l}0.525 \\
0.525 \\
0.520 \\
0,301\end{array}$ & $\begin{array}{l}0.483 \\
0.478 \\
0.475 \\
0.200\end{array}$ & $\begin{array}{l}0.570^{a} \\
0.552^{b} \\
0.515^{a, b} \\
0.001^{*}\end{array}$ & $\begin{array}{l}0.373 \\
0.381 \\
0.372 \\
0.153\end{array}$ \\
\hline & $\sum_{\sum}^{0}$ & $\begin{array}{l}\text { Subgroup } 4 \\
\text { Subgroup } 5 \\
\text { Subgroup } 6 \\
\text { p-values }\end{array}$ & $\begin{array}{l}1.023 \\
1.021 \\
1.027 \\
0.307\end{array}$ & $\begin{array}{l}0.831 \\
0.830 \\
0.831 \\
0.972\end{array}$ & $\begin{array}{l}0.700 \\
0.704 \\
0.717 \\
0.409\end{array}$ & $\begin{array}{l}0.568^{\mathrm{a}} \\
0.564^{\mathrm{b}} \\
0.547^{\mathrm{a}, \mathrm{b}} \\
0.002^{*}\end{array}$ & $\begin{array}{l}0.372^{\mathrm{a}} \\
0.370 \\
0.358^{\mathrm{a}} \\
0.031^{*}\end{array}$ \\
\hline
\end{tabular}

$* p<0.05$ statistically significant.

${ }^{a b c}$ Same letters in the same column within the same section indicate a statistically significant difference at $p<0.05$. 
Table 2. Mean inner and outer widths $(\mathrm{mm})$ of canals by torque values

\begin{tabular}{|c|c|c|c|c|c|c|c|c|c|c|c|c|}
\hline & & & \multicolumn{2}{|c|}{ Orifice } & \multicolumn{2}{|c|}{ Half-way to orifice } & \multicolumn{2}{|c|}{ Beginning of curve } & \multicolumn{2}{|c|}{ Apex of curve } & \multicolumn{2}{|c|}{$0.5 \mathrm{~mm}$ from endpoint } \\
\hline & & & Inner & Outer & Inner & Outer & Inner & Outer & Inner & Outer & Inner & Outer \\
\hline \multirow{8}{*}{$\begin{array}{l}\text { 윽 } \\
\text { 인 } \\
\text { ํํํ }\end{array}$} & \multirow{4}{*}{$\underline{\tilde{m}}$} & Subgroup 1 & 0.082 & $0.071^{a, b}$ & $0.083^{\mathrm{a}}$ & 0.123 & $0.161^{\mathrm{a}}$ & $0.067^{\mathrm{a}}$ & $0.119^{a}$ & $0.229^{a}$ & $0.031^{a}$ & 0.169 \\
\hline & & Subgroup 2 & 0.086 & $0.048^{a}$ & 0.089 & 0.126 & 0.157 & $0.073^{b}$ & $0.092^{a, b}$ & $0.247^{b}$ & 0.039 & 0.169 \\
\hline & & Subgroup 3 & 0.079 & $0.048^{\mathrm{b}}$ & $0.094^{\mathrm{a}}$ & 0.116 & $0.144^{\mathrm{a}}$ & $0.087^{a, b}$ & $0.110^{\mathrm{b}}$ & $0.198^{a, b}$ & $0.045^{a}$ & 0.158 \\
\hline & & p-values & 0.711 & $0.003 *$ & $0,009 *$ & 0.073 & $0.046 *$ & $0.001 *$ & $0.001 *$ & $0.001^{*}$ & $0.004 *$ & 0.052 \\
\hline & \multirow{4}{*}{$\sum_{\sum}^{0}$} & Subgroup 4 & 0.262 & 0.246 & 0.249 & 0.263 & 0.333 & $0.122^{\mathrm{a}}$ & $0.164^{\mathrm{a}}$ & $0.189^{a, b}$ & 0.063 & $0.141^{\mathrm{a}}$ \\
\hline & & Subgroup 5 & 0.270 & 0.254 & 0.259 & $0.270^{\mathrm{a}}$ & 0.342 & $0.117^{\mathrm{b}}$ & 0.179 & $0.174^{\mathrm{a}, \mathrm{c}}$ & 0.064 & $0.142^{\mathrm{b}}$ \\
\hline & & Subgroup 6 & 0.264 & 0.266 & 0.259 & $0.259^{a}$ & 0.358 & $0.101^{a, b}$ & $0.197^{a}$ & $0.130^{\mathrm{b}, \mathrm{c}}$ & 0.059 & $0.126^{a, b}$ \\
\hline & & p-values & 0.776 & 0.063 & 0.100 & $0.020 *$ & 0.061 & $0.004^{*}$ & $0.001 *$ & $0.001^{*}$ & 0.187 & $0.012 *$ \\
\hline
\end{tabular}

$* \mathrm{p}<0.05$ statistically significant.

${ }^{a b c}$ Same letters in the same column within the same section indicate a statistically significant difference at $\mathrm{p}<0.05$.

Table 3. Mean distance $(\mathrm{mm})$ of absolute transportation by torque values

\begin{tabular}{|c|c|c|c|c|c|c|c|}
\hline & & & Orifice & $\begin{array}{l}\text { Half-way to } \\
\text { orifice }\end{array}$ & $\begin{array}{l}\text { Beginning of } \\
\text { curve }\end{array}$ & Apex of curve & $\begin{array}{l}0.5 \mathrm{~mm} \text { from } \\
\text { endpoint }\end{array}$ \\
\hline \multirow{2}{*}{$\begin{array}{l}\text { 음 } \\
\text { 훙 } \\
\frac{0}{5}\end{array}$} & $\underline{\underline{m}}$ & $\begin{array}{l}\text { Subgroup } 1 \\
\text { Subgroup } 2 \\
\text { Subgroup } 3 \\
\text { p-values }\end{array}$ & $\begin{array}{l}0.033 \\
0.040 \\
0.036 \\
0.668\end{array}$ & $\begin{array}{l}0.040^{\mathrm{a}} \\
0.037^{\mathrm{b}} \\
0.022^{\mathrm{a}, \mathrm{b}} \\
0,012^{*}\end{array}$ & $\begin{array}{l}0.094^{\mathrm{a}} \\
0.083^{\mathrm{b}} \\
0.057^{\mathrm{a}, \mathrm{b}} \\
0.001^{*}\end{array}$ & $\begin{array}{l}0.109^{\mathrm{a}} \\
0.155^{\mathrm{a}, \mathrm{b}} \\
0.088^{\mathrm{b}} \\
0.001^{*}\end{array}$ & $\begin{array}{l}0.137^{\mathrm{a}} \\
0.134^{\mathrm{b}} \\
0.113^{\mathrm{a}, \mathrm{b}} \\
0.004^{*}\end{array}$ \\
\hline & $\sum_{\sum}^{O}$ & $\begin{array}{l}\text { Subgroup } 4 \\
\text { Subgroup } 5 \\
\text { Subgroup } 6 \\
\text { p-values }\end{array}$ & $\begin{array}{l}0,028 \\
0.037 \\
0.033 \\
0.657\end{array}$ & $\begin{array}{l}0.018 \\
0.021 \\
0.017 \\
0.713\end{array}$ & $\begin{array}{l}0.210^{\mathrm{a}} \\
0.225^{\mathrm{b}} \\
0.256^{\mathrm{a}, \mathrm{b}} \\
0.003^{*}\end{array}$ & $\begin{array}{l}0.037^{\mathrm{a}} \\
0.021^{\mathrm{b}} \\
0.062^{\mathrm{a}, \mathrm{b}} \\
0.001^{*}\end{array}$ & $\begin{array}{l}0.078 \\
0.078 \\
0.067 \\
0.223\end{array}$ \\
\hline
\end{tabular}

$* p<0.05$ statistically significant.

abc Same letters in the same column within the same section indicate a statistically significant difference at $\mathrm{p}<0.05$.

\section{Canal aberrations}

The incidences of aberrations associated with each torque value are shown in Table 4. Several ledges were created in all subgroups but there were no significant differences ( $p>0.05$ ) between the subgroups in the $\mathrm{K} 3$ and Mtwo groups.

There were no significant differences ( $p>0.05$ ) between the torque values in terms of instrument fracture and deformation in the K3 group. No instrument fractures occured in the Mtwo group. There were significant differences $(p<0.05)$ for instrument deformation between the torque values in the Mtwo group. Many deformations occured with the Mtwo files in the subgroup 6. Neither perforations nor zips and elbow were observed for either subgroup.

\section{Change of curvature}

The change of curvature between pre- and post-instrumentation was found in all canals. Table 5 shows the mean changes of curvature. The change of
Table 4. Incidence of aberrations by torque values

\begin{tabular}{|c|c|c|c|c|c|}
\hline & & & Ledge & $\begin{array}{l}\text { Instrument } \\
\text { fracture }\end{array}$ & $\begin{array}{l}\text { Instrument } \\
\text { deformation }\end{array}$ \\
\hline \multirow{6}{*}{ 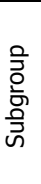 } & \multirow{3}{*}{$\underline{m}$} & Subgroup 1 & 5 & 1 & 1 \\
\hline & & Subgroup 2 & 7 & 2 & 0 \\
\hline & & Subgroup 3 & 6 & 0 & 1 \\
\hline & \multirow{3}{*}{$\sum_{\sum}^{P}$} & Subgroup 4 & 10 & 0 & 0 \\
\hline & & Subgroup 5 & 13 & 0 & 0 \\
\hline & & Subgroup 6 & 7 & 0 & 8 \\
\hline
\end{tabular}

Table 5. Changes of curvature (degree)

\begin{tabular}{|c|c|c|c|}
\hline & & & mean \\
\hline \multirow{7}{*}{$\begin{array}{l}\text { 윽 } \\
\text { 은 } \\
\text { 을 }\end{array}$} & \multirow{4}{*}{$\underline{m}$} & Subgroup 1 & $5.292^{\mathrm{a}}$ \\
\hline & & Subgroup 2 & 4.940 \\
\hline & & Subgroup 3 & $4.348^{a}$ \\
\hline & & p-values & $0.045^{*}$ \\
\hline & \multirow{4}{*}{$\sum_{\sum}^{\stackrel{0}{\Sigma}}$} & Subgroup 4 & 6.690 \\
\hline & & Subgroup 5 & 6.605 \\
\hline & & Subgroup 6 & 6.930 \\
\hline & & $\mathrm{p}$-values & 0.698 \\
\hline
\end{tabular}

$* p<0.05$ statistically significant. Same letters indicate a statistically significant difference at $p<0.05$. 
curvature for K3 group was statistically different ( $p<$ 0.05 ). The change of curvature was the smallest in the subgroup 3. The differences between the subgroups of the Mtwo group were not statistically significant $(p>$ 0.05).

\section{Change in working length}

None of the canals became blocked with resin debris for both groups (Mtwo and K3). None of the canals showed overextension of preparation, whereas a loss of working distance was found in all canals for both groups (Mtwo and K3). The mean loss of working length that occurred with different torque values is listed in Table 6. The differences between the three subgroups were not statistically significant $(p>0.05)$ neither in the $\mathrm{K} 3$ group nor in the Mtwo group.

Table 6. Mean loss of working length $(\mathrm{mm})$ by torque values

\begin{tabular}{|c|c|c|c|}
\hline & & & mean \\
\hline \multirow{2}{*}{$\begin{array}{l}\text { 음 } \\
\text { 은 } \\
\text { ตำ }\end{array}$} & $\underline{\tilde{2}}$ & $\begin{array}{l}\text { Subgroup } 1 \\
\text { Subgroup } 2 \\
\text { Subgroup } 3 \\
\text { p-values }\end{array}$ & $\begin{array}{l}0.221 \\
0.217 \\
0.169 \\
0.270\end{array}$ \\
\hline & $\sum_{\sum}^{\text {O }}$ & $\begin{array}{l}\text { Subgroup } 4 \\
\text { Subgroup } 5 \\
\text { Subgroup } 6 \\
\text { p-values }\end{array}$ & $\begin{array}{l}0.159 \\
0.180 \\
0.141 \\
0.439\end{array}$ \\
\hline
\end{tabular}

$* p<0.05$ significant

\section{DISCUSSION}

The objective of root canal instrumentation is to maintain the original canal curvature in order to produce a continuously tapering and conical form with the smallest diameter at the endpoint of the preparation. ${ }^{25}$ The problem of straightening occurs mostly in severely curved canals and at the apex of the canal. ${ }^{26}$ In recent years, a great number of reports described the advantages of nickel-titanium rotary instruments. ${ }^{3,27-29}$ These instruments have the potential to prepare root canals rapidly and safely to produce relatively few aberrations during the root canal preparation. ${ }^{23}$

In the present study, transparent resin blocks were selected for experimentation. Use of simulated canals in resin blocks does not reflect the action of the instruments in root canals of natural teeth because of the differences in the surface texture, hardness and cross-section. ${ }^{1}$ However the use of a simulated canal in a resin block allows standardization the root canal preparation and is an ideal experimental model to allow direct comparison of the shaping ability of different instruments. ${ }^{30}$

In several studies the transparent resin blocks were covered adhesive tape during the preparation phase. ${ }^{23,29,31}$ In this study each resin block was covered with aluminium leaf during the preparation to prepare the canals only tactile sensation. However, Martin and Blasković-Subat ${ }^{32}$ did not cover the transparent resin blocks during the canal instrumentation procedure, because of controlling the influence of every instrument.

The torque values of the present study were determined by inspecting the preset torque values of $\mathrm{K} 3$ and Mtwo file systems in the file library of the VDW.GOLD motor. Torque values were determined different for each file system because the values were set for a file system would be very high or very low for another file system. Because of the different torque values were applied to the K3 and Mtwo groups, they have not been compared with each other.

In the present study, mean total width of the canal increased as the torque value decreased in groups of K3 and Mtwo. This finding may be result of the low torque would reduce cutting efficiency of the instrument, and instrument progression in the canal would be difficult; the operator would then tend to force the instrument. ${ }^{18}$ Therefore, instrument may used with more in-and-out motion to reach to the working length when the low torque values used.

Excessive dentin removal in a single direction within the canal rather than in all directions equidistantly from the main toot axis causes what is known as a canal transportation. ${ }^{33}$ Previous studies determined that various factor effect to the canal transportation. Schäfer et al. ${ }^{6}$ and Tasdemir et al. ${ }^{34}$ evaluated root canal preparation and found that less transportation occurred with $\mathrm{Ni}$-Ti rotary instruments than stainless steel hand files. Lam et al. ${ }^{35}$ reported that apical and mid-curve transportation increases with file size for all types of instrument. Poulsen et al. ${ }^{36}$ found that rotational speed did not affect to the root canal morphology during the preparation.

However, a literature review showed that this is the first study that evaluated the effect of different torque values applied to $\mathrm{Ni}-\mathrm{Ti}$ rotary instruments on curved canal preparation in vitro. In the present study 
except $A C$, less transportation occurred with $\mathrm{K} 3$ instruments in the subgroup 3 in which torque was high. High transportation occurred with Mtwo instruments in the subgroup 6 at $B C$ and $A C$.

In several studies, files were used to determined canal configuration. ${ }^{37-39}$ However, the file will approximate the actual canal shape but may not confirm exactly, especially where a canal is large and the file does not remain centered. ${ }^{38}$ Therefore, the degree of curvature was determined using the method describing by Bone and Moule ${ }^{24}$ and files do not used to determine the canal curvature in the present study. Changes on canal curvature after the root canal preparation were investigated in many studies. Pettiette et al. ${ }^{40}$ showed that the original curvature of canal was better maintained with $\mathrm{Ni}-\mathrm{Ti}$ files. Schäfer and Schlingemann ${ }^{41}$ determined that $\mathrm{K} 3$ instruments maintained the original canal curvature significantly better than K-Flexofiles. Kuzekanani et al. ${ }^{16}$ demonstrated that the Mtwo system gave smaller change in canal curvature and thus was better for maintaining the original canal shape of the root canal with less transportation than ProTaper instruments. In the present study, change in canal curvature was the smallest with $\mathrm{K} 3$ system in the subgroup 3 .

During the present study, no zip-elbow or perforations were created with the both $\mathrm{K} 3$ and Mtwo systems; however, ledge formations occurred in all subgroups. Sonntag et al. ${ }^{17}$ showed that $20 \%$ zip, $32 \%$ elbow, $0 \%$ ledge formation were occured with the Mtwo system and $46.9 \%$ zip, $46.9 \%$ elbow, $0 \%$ ledge formation was occurred with $\mathrm{K} 3$ system (The NiTi systems were driven by low torque motor Endo IT professional.).

One of the major concerns when using nickeltitanium instruments is instrument separation and deformation. In the present study none of the Mtwo instruments fractured; it could be because of the fact that the increasing pitch length from the tip to the shaft of these instruments ${ }^{11}$, but 8 Mtwo files were deformed in the subgroup 6 where the torque was highest. When using the K3 system, 1 file fractured and 1 file deformed in the subgroup 1, 2 files fractured in the subgroup 2 and 1 file deformed in the subgroup 3. The previous comparative studies involving Mtwo and Protaper instruments showed that no instrument separated during the instrumentation. ${ }^{16,42}$ Another recent study which used individual torque limit and rotational speed programmed in the file library of the Endo IT motor for each RaCe, K3 and Mtwo file noted that six RaCe files, four K3 instruments and no Mtwo instruments fractured; however a total of 8 Mtwo instruments permanently deformed. ${ }^{11}$ Yared et al. ${ }^{43}$ reported that instrument locking, deformation and separation did not occur with any of the three torque values $(20,30$, and $55 \mathrm{Ncm})$. Also Yared et al. ${ }^{43}$ demonstrated that in the study motors that set torque values at minimal levels may not be useful for experienced operators. Yared et al. ${ }^{44}$ had also reported similar findings in another study. On the other hand despite the use of low torque motor in the present study, instrument deformation was increased with high torque in the Mtwo group.

In the present study, none of the canals became blocked with resin shavings. However, the only change of a working length was a loss of working distance. It was possible with all torque values to control the working length well. This finding is in agreement with several observations of other studies in that only small mean changes in working length occured with rotary $\mathrm{Ni}-\mathrm{Ti}$ instruments. ${ }^{6,11,45-47}$ These changes may be probably due to minor canal straightening during canal enlargement or lack of length control by the operator. ${ }^{46}$

The results of this study revealed that $\mathrm{K} 3$ instruments prepared curved canals with minimal transportation, when the torque value increased; on the contrary, greater values of absolute transportation occured with Mtwo instruments. The effects of the torque on root canal preparations could vary depending on the type and taper of the file, and preparation techniques.

\section{REFERENCES}

1. Peters OA. Current challenges and concepts in the preparation of root canal systems: a review. J Endod 2004;30:559-67.

2. Cohen S, Burns RC. Pathways of the pulp. 8 ed. St Louise; CV Mosby: 2002. p. 231-91.

3. Schäfer $E$, Schulz-Bongert $U$, Tulus G. Comparison of hand stainless steel and nickel titanium rotary instrumentation: a clinical study. J Endod 2004;30:432-5.

4. Walia HM, Brantley WA, Gerstein H. An initial investigation of the bending and torsional 
properties of Nitinol root canal files. J Endod 1988;14:346-51.

5. Schäfer E. Shaping ability of Hero 642 rotary nickel-titanium instruments and stainless steel hand K-Flexofiles in simulated curved root canals. Oral Surg Oral Med Oral Pathol Oral Radiol Endod 2001;92:215-20.

6. Schäfer $E$, Florek H. Efficiency of rotary nickeltitanium K3 instruments compared with stainless steel hand K-Flexofile. Part 1. Shaping ability in simulated curved canals. Int Endod J 2003;36:199-207.

7. Thompson SA, Dummer PM. Shaping ability of Hero 642 rotary nickel-titanium instruments in simulated root canals: Part 2. Int Endod J 2000;33:255-61.

8. Thompson SA, Dummer PM. Shaping ability of ProFile.04 Taper Series 29 rotary nickel-titanium instruments in simulated root canals. Part 2. Int Endod J 1997;30:8-15.

9. Thompson SA, Dummer PM. Shaping ability of NT Engine and McXim rotary nickel-titanium instruments in simulated root canals. Part 2. Int Endod J 1997;30:270-8.

10. Thompson SA. An overview of nickel-titanium alloys used in dentistry. Int Endod J 2000;33:297-310.

11. Schäfer $E$, Erler M, Dammaschke T. Comparative study on the shaping ability and cleaning efficiency of rotary Mtwo instruments. Part 1. Shaping ability in simulated curved canals. Int Endod J 2006;39:196-202.

12. Malagino VA, Grande NM, Plotino G, Somma F. The Mtwo NiTi rotary system for root canal preparation. Roots 2006;3:67-70.

13. Bergmans L, Van Cleynenbreugel J, Wevers M, Lambrechts $P$. Mechanical root canal preparation with $\mathrm{NiTi}$ rotary instruments: rationale, performance and safety. Status report for the American Journal of Dentistry. Am J Dent 2001;14:324-33.

14. Aydin C, Inan U, Yasar S, Bulucu B, Tunca YM. Comparison of shaping ability of RaCe and Hero Shaper instruments in simulated curved canals. Oral Surg Oral Med Oral Pathol Oral Radiol Endod 2008;105:e92-7.

15. Karagöz-Küçükay I, Ersev $H$, Engin-Akkoca $E$, Küçükay S, Gürsoy T. Effect of rotational speed on root canal preparation with Hero 642 rotary $\mathrm{Ni}$-Ti instruments. J Endod 2003;29:447-9.

16. Kuzekanani M, Walsh $\sqcup$, Yousefi MA. Cleaning and shaping curved root canals: Mtwo vs ProTaper instruments, a lab comparison. Indian J Dent Res 2009;20:268-70.

17. Sonntag D, Ott M, Kook K, Stachniss V. Root canal preparation with the $\mathrm{NiTi}$ systems K3, Mtwo and ProTaper. Aust Endod J 2007;33:7381.

18. Yared GM, Bou Dagher FE, Machtou P. Failure of ProFile instruments used with high and low torque motors. Int Endod J 2001;34:471-5.

19. Hubscher W, Barbakow F, Peters OA. Root canal preparation with FlexMaster: asessment of torque and force in relation to canal anatomy. Int Endod J 2003;36:883-90.

20. Yared G, Kulkarni GK, Ghossayn F. An in vitro study of the torsional properties of new and used K3 instruments. Int Endod J 2003;36:764-9.

21. Berutti $E$, Negro AR, Lendini M, Pasqualini D. Influence of manual preflaring and torque on the failure rate of ProTaper rotary instruments. J Endod 2004;30:228-30.

22. Gambarini G. Cyclic fatigue of nickel-titanium rotary instruments after clinical use with low- and high-torque endodontic motors. J Endod 2001;27:772-4.

23. Calberson FL, Deroose CA, Hommez GM, Raes $H$, De Moor RJ. Shaping ability of GT ${ }^{\mathrm{TM}}$ Rotary Files in simulated resin root canals. Int Endod J 2002;35:607-14.

24. Bone J, Moule AJ. The nature of curvature of palatal canals in maxillary molar teeth. Int Endod J 1986;19:178-86.

25. Cohen S, Burns RC. Pathways of the pulp. 3 ed. St Louise; CV Mosby: 1984. p. 175-204.

26. Weine FS, Kelly RF, Lio PJ. The effect of preparation procedures on original canal shape and on apical foramen shape. J Endod 1975;1:255-62.

27. Guelzow A, Stamm O, Martus P, Kielbassa AM. Comparative study of six rotary nickel-titanium systems and hand instrumentation for root canal preparation. Int Endod J 2005;38:743-52.

28. Park H. A comparison of Greater Taper files, ProFiles, and stainless steel files to shape curved root canals. Oral Surg Oral Med Oral Pathol Oral

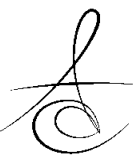


Radiol Endod 2001;91:715-8.

29. Schäfer E, Lohmann D. Efficiency of rotary nickel-titanium FlexMaster instruments compared with stainless steel hand K-Flexofile--Part 1. Shaping ability in simulated curved canals. Int Endod J 2002;35:505-13.

30.Schäfer E, Tepel J, Hoppe W. Properties of endodontic hand instruments used in rotary motion. Part 2. Instrumentation of curved canals. J Endod 1995;21:493-7.

31. Lim KC, Webber J. The validity of simulated root canals for the investigation of the prepared root canal shape. Int Endod J 1985;18:240-6.

32. Martin G, Blasković-Subat V. Preparation of simulated root canals using the Macfile, Canal Master $\mathrm{U}$ and $\mathrm{K}$-Flexofile. Int Endod J 1997;30:160-6.

33. Hartmann MS, Barletta FB, Camargo Fontanella VR, Vanni JR. Canal transportation after root canal instrumentation: a comparative study with computed tomography. J Endod 2007;33:962-5.

34. Tasdemir $\mathrm{T}$, Aydemir $\mathrm{H}$, Inan $\mathrm{U}$, Unal $\mathrm{O}$. Canal preparation with Hero 642 rotary $\mathrm{Ni}-\mathrm{Ti}$ instruments compared with stainless steel hand $\mathrm{K}$-file assessed using computed tomography. Int Endod J 2005;38:402-8.

35. Lam TV, Lewis DJ, Atkins DR, Macfarlane RH, Clarkson RM, Whitehead MG, Brockhurst PJ, Moule AJ. Changes in root canal morphology in simulated curved canals over-instrumented with a variety of stainless steel and nickel titanium files. Aust Dent J 1999;44:12-9.

36. Poulsen WB, Dove SB, del Rio CE. Effect of nickel-titanium engine-driven instrument rotational speed on root canal morphology. J Endod 1995;21:609-12.

37. Bramante CM, Betti LV. Comparative analysis of curved root canal preparation using nickeltitanium instruments with or without EDTA. J Endod 2000;26:278-80.

38. Cunningham $\mathrm{C}$, Senia ES. A three-dimensional study of canal curvatures in the mesial roots of mandibular molars. J Endod 1992;18:294-300.

39. Schäfer E, Diez C, Hoppe W, Tepel J. Roentgenographic investigation of frequency and degree of canal curvatures in human permanent teeth. J Endod 2002;28:211-6.
40. Pettiette MT, Metzger Z, Phillips C, Trope M. Endodontic complications of root canal therapy performed by dental students with stainless-steel K-files and nickel-titanium hand files. J Endod 1999;25:230-4.

41. Schäfer $E$, Schlingemann R. Efficiency of rotary nickel-titanium K3 instruments compared with stainless steel hand K-Flexofile. Part 2. Cleaning effectiveness and shaping ability in severely curved root canals of extracted teeth. Int Endod J 2003;36:208-17.

42. Göktürk $H$, Yücel AÇ, Şişman A. The shaping ability of five different nickel-titanium rotary instruments in simulated root canals. J Dent Fac Atatürk Uni 2014;24:58-66.

43. Yared GM, Bou Dagher FE, Machtou P, Kulkarni GK. Influence of rotational speed, torque and operator proficiency on failure of Greater Taper files. Int Endod J 2002;35:7-12.

44. Yared GM, Bou Dagher FE, Machtou P. Influence of rotational speed, torque and operator's proficiency on ProFile failures. Int Endod $\mathrm{J}$ 2001;34:47-53.

45. Kum KY, Spangberg L, Cha BY, Il-Young J, Seung-Jong L, Chan-Young L. Shaping ability of three ProFile rotary instrumentation techniques in simulated resin root canals. J Endod 2000;26:719-23.

46. Thompson SA, Dummer PM. Shaping ability of Hero 642 rotary nickel-titanium instruments in simulated root canals: Part 1. Int Endod J 2000;33:248-54.

47. Vahid A, Roohi N, Zayeri F. A comparative study of four rotary NiTi instruments in preserving canal curvature, preparation time and change of working length. Aust Endod J 2009;35:93-7.

\section{Yazışma Adresi:}

Yrd. Doç. Dr. Demet ALTUNBAŞ

Department of Endodontics, Faculty of Dentistry, Cumhuriyet University, Sivas, Turkey

Tel: 00-90-346-2191010/2764

Fax: 00-90-346-2191237

e-mail: dt_demmet@hotmail.com 